\title{
PENGARUH INTELLECTUAL CAPITAL DAN ISLAMICITY PERFORMANCE INDEX TERHADAP KINERJA KEUANGAN PERBANKAN SYARIAH DI INDONESIA
}

\author{
Anita Nur Khasanah \\ Prodi Akuntansi Universitas Negeri Yogyakarta \\ anurkha@gmail.com
}

\begin{abstract}
Abstrak : Pengaruh Intellectual Capital Dan Islamicity Performance Index Terhadap Kinerja Keuangan Perbankan Syariah Di Indonesia. Penelitian ini bertujuan untuk mengetahui pengaruh: (1) Intellectual Capital terhadap Kinerja Keuangan Perbankan Syariah, (2) Profit Sharing Ratio terhadap Kinerja Keuangan Perbankan Syariah, (3) Zakat Performing Ratio terhadap Kinerja Keuangan Perbankan Syariah, (4) Equitable Distribution Ratio terhadap Kinerja Keuangan Perbankan Syariah, (5) Islamic Income vs Non-Islamic Income terhadap Kinerja Keuangan Perbankan Syariah, dan (6) Intellectual Capital, Profit Sharing Ratio, Zakat Performing Ratio, Equitable Distribution Ratio, dan Islamic Income vs Non-Islamic Income secara simultan terhadap Kinerja Keuangan Perbankan Syariah. Teknik analisis data menggunakan analisis statistik deskriptif data, uji asumsi klasik, dan analisis regresi linier. Berdasarkan hasil penelitian dapat disimpulkan: (1) Terdapat pengaruh positif signifikan Intellectual Capital terhadap Kinerja Keuangan, (2) Terdapat pengaruh signifikan Profit Sharing Ratio terhadap Kinerja Keuangan, (3) Tidak terdapat pengaruh signifikan Zakat Performing Ratio terhadap Kinerja Keuangan, (4) Tidak terdapat pengaruh signifikan Equitable Distribution Ratio terhadap Kinerja Keuangan, (5) Tidak terdapat pengaruh signifikan Islamic Income vs Non-Islamic Income terhadap Kinerja Keuangan, (6) Terdapat pengaruh positif signifikan Intellectual Capital, Profit Sharing Ratio, Zakat Performing Ratio, Equitable Distribution Ratio, dan Islamic Income vs NonIslamic Income secara simultan terhadap Kinerja Keuangan.
\end{abstract}

Kata Kunci: Kinerja Keuangan, Intellectual Capital, Profit Sharing Ratio, Zakat Performing Ratio, Equitable Distribution Ratio, Islamic Income vs Non-Islamic Income

\begin{abstract}
The Effect Of Intellectual Capital And Islamicity Performance Index On Financial Performance Of Islamic Banks In Indonesia. This research is conducted to examine the effect of: (1) Intellectual Capital on financial performance of Islamic Banks, (2) Profit Sharing Ratio on financial performance of Islamic Banks, (3) Zakat Performing Ratio on financial performance of Islamic Banks, (4) Equitable Distribution Ratio on financial performance of Islamic Banks, (5) Islamic Income vs NonIslamic Income on financial performance of Islamic Banks, and (6) Intellectual Capital, Profit Sharing Ratio, Zakat Performing Ratio, Equitable Distribution Ratio, and Islamic Income vs Non-Islamic Income, together, affected on financial performance of Islamic Banks. The data analysis technique used descriptive statistical analysis, the classical assumption test, linear regression analysis. The result shows that: (1) There is a significant positive effect of Intellectual Capital on Financial Performance, (2) There is significant influence of Profit Sharing Ratio on Financial Performance, (3) There is no significant effect of Zakat Performing Ratio on Financial Performance, (4) There is no significant influence of the Equitable Distribution Ratio on Financial Performance, (5) There is no significant influence of Islamic Income vs Non-Islamic Income on Financial Performance, (6) There is a significant positive effect of Intellectual Capital, Profit Sharing Ratio, Zakat Performing Ratio, Equitable Distribution Ratio, and Islamic Income vs Non-Islamic Income, together, affected Financial Performance.
\end{abstract}

Keywords: Financial Performance, Intellectual Capital, Profit Sharing Ratio, Zakat Performing Ratio, Equitable Distribution Ratio, Islamic Income vs Non-Islamic Income 


\section{JURNAL NOMINAL / VOLUME V NOMOR 1 / TAHUN 2016}

\section{PENDAHULUAN}

Seiring dengan perkembangan teknologi dan ilmu pengetahuan, perbankan syariah mengalami perkembangan dari tahun ke tahun. Sejak tahun 2010, tingkat pertumbuhan aset perbankan syariah mencapai angka seratus triliun rupiah pada Desember 2010. Sedangkan pada lima tahun terakhir, rata-rata pertumbuhan aset perbankan syariah mencapai $65 \%$ per tahun. Di samping adanya peningkatan total aset, perbankan syariah juga mengalami pertumbuhan dalam jumlah bank. Statistik perbankan syariah yang diterbitkan Otoritas Jasa Keuangan tahun 2015, menunjukkan bahwa pada tahun 2010 Bank Umum Syariah mengalami pertumbuhan pesat. Pada awalnya Bank Umum Syariah hanya berjumlah 6 bank, kemudian bertambah banyak menjadi 11 bank pada tahun 2010 . Selain itu, jumlah kantor Bank Umum Syariah meningkat dari 711 kantor menjadi 1.215 kantor. Peningkatan ini membuktikan bahwa masih terdapat peluang dalam perbankan syariah. Oleh karena itu perbankan syariah perlu mendapat perhatian lebih agar dapat membantu perekonomian Islam di Indonesia.

Pada tahun-tahun terakhir, terdapat penurunan kinerja keuangan perbankan syariah. Hal ini ditunjukkan oleh nilai ROA Bank Umum Syariah (BUS) dan Unit Usaha Syariah (UUS) yang tidak hanya mengalami kenaikan, tetapi juga mengalami penurunan.
Pada Statistik Perbankan Syariah tahun 2015 dapat dilihat bahwa pada tahun 2010, ROA BUS dan UUS menunjukkan angka 1,67. Pada tahun 2011 dan 2012, ROA mengalami peningkatan menjadi 1,79 dan 2,14. Mulai pada tahun 2013 mengalami penurunan sampai dengan tahun 2015. ROA BUS dan UUS tahun 2013, 2014, dan 2015 secara berturut-turut yaitu 2,00; 0,79; dan 0,49.

Perbankan syariah perlu untuk meningkatkan strategi yang dijalankan. Perbankan syariah perlu mengubah pola manajemen perusahaan dari pola manajemen berdasarkan tenaga kerja (labor based business) menjadi pola manajemen berdasarkan pengetahuan (knowledge based business). Pola manajemen berdasarkan pengetahuan mendorong perusahaan untuk dapat mengelola intellectual capital secara efektif. Intelectual capital merupakan bagian dari aset tidak berwujud yang dimiliki perusahaan. Aset tidak berwujud perusahaan seperti intellectual capital memiliki potensi untuk meningkatkan nilai tambah perusahaan.

Pengukuran intellectual capital memang belum ditetapkan secara pasti. Akan tetapi, dalam forum Organisation For Economic Co Operation And Development (OECD) pada bulan Juni 1999 disebutkan bahwa Intellectual Capital merupakan aset yang penting bagi perusahaan dalam menciptakan nilai dan memenangkan nilai (value). Di Indonesia, intellectual capital diatur dalam 


\section{JURNAL NOMINAL / VOLUME V NOMOR 1 / TAHUN 2016}

PSAK No. 19 (revisi tahun 2000) tentang Aktiva Tak Berwujud. Walaupun begitu, intellectual capital masih belum disebutkan secara jelas. Oleh karena itu, masih banyak perbankan syariah yang belum memberikan perhatian terhadap pengukuran intellectual capital.

Pulic (1998) mengungkapkan pengukuran intellectual capital yaitu dengan menggunakan VAIC (Value Added Intellectual Coefficient). VAIC merupakan pengukuran secara tidak langsung dengan suatu ukuran untuk menilai efisiensi dari nilai tambah sebagai hasil dari kemampuan intelektual perusahaan. Komponen dalam VAIC yaitu physical capital (VACA), human capital (VAHU), dan structural capital (STVA).

Banyaknya perbankan syariah yang belum menjalankan bisnis sesuai prinsip syariah merupakan salah satu masalah yang menyebabkan perkembangan perbankan syariah terhambat (Kompas.com, 13 Agustus 2012). Perlu digarisbawahi bahwa perbankan syariah memiliki perbedaan dengan perbankan konvensional, dan dikarenakan terdapat banyak perbankan syariah yang belum menjalankan bisnis sesuai dengan prinsip syariah, maka terdapat masalah pula pada ketersediaan produk dan standarisasi produk perbankan syariah.

Melihat adanya masalah ketidaksesuaian pelaksanaan dengan prinsip syariah, maka dari itu perbankan syariah perlu diukur dari segi tujuan syariah. Dengan begitu, akan diketahui apakah kinerja perbankan yang telah dijalankan sesuai dengan prinsip syariah akan mempengaruhi kinerja keuangan perbankan syariah. Shahul Hameed et. al. (2004) menyajikan alternatif pengukuran kinerja untuk Perbankan Syariah, yaitu dengan menggunakan Islamicity Indices. Islamicity Indices ini terdiri dari dua komponen, yaitu Islamicity Disclosure Index dan Islamicity Performance Index. Pengukuran dari segi tujuan syariah dapat menggunakan Islamicity performance index. Komponen Islamicity performance index meliputi profit sharing ratio, zakat performing ratio, equitable distribution ratio, director-employees welfare ratio, Islamic investmen vs non-Islamic investment, Islamic income vs non-Islamic income, dan AAOIFI index.

Profit sharing ratio menunjukkan seberapa jauh perbankan syariah mencapai eksistensi dengan perolehan bagi hasil dari pemberian pembiayaan kepada nasabah. Bagi hasil merupakan komponen penting dalam perbankan syariah, sehingga pembiayaan bagi hasil menjadi inti dari pembiayaan bank syariah (Kompasiana.com, 26 Juni 2015). Pada dasarnya, terdapat empat jenis akad pembiayaan bagi hasil pada perbankan syariah, yaitu mudharabah, musyarakah, muzara'ah, dan musaqah. Akan tetapi, akad yang banyak dikenal hanya akad mudharabah dan musyarakah. 


\section{JURNAL NOMINAL / VOLUME V NOMOR 1 / TAHUN 2016}

Walaupun pembiayaan bagi hasil merupakan pembiayaan inti dari perbankan syariah, pembiayaan ini masih berada di bawah pembiayaan jual-beli (murabahah), sehingga nilai profit sharing ratio masih rendah. Berdasarkan statistik perbankan syariah, pada tahun 2014 pembiayaan mudharabah dan musyarakah adalah 14,35 triliun dan 49,336 triliun, sedangkan jumlah pembiayaan murabahah yaitu sebesar 115,60 triliun. Data di atas menunjukkan bahwa pelaksanaan pembiayaan bagi hasil perbankan syariah di Indonesia masih rendah.

Selain profit sharing ratio, zakat performing ratio juga menjadi salah satu tujuan ekonomi Islam, salah satu indikator dilaksanakannya prinsip-prinsip Islam dalam perbankan syariah. Kinerja perbankan Islam harus berdasarkan pembayaran zakat yang dilakukan oleh bank. Menurut Lembaga Amil Zakat (Republika, 26 April 2016) perbankan syariah belum siap dalam pengelolaan zakat dan penyaluran zakat, dan tercermin pada nilai zakat performing ratio yang rendah.

Equitable distribution ratio merupakan indikator pelaksanaan prinsip syariah, di mana menekankan adanya keadilan dengan pemerataan pendapatan. Dari rasio ini diketahui besar rata-rata distribusi pendapatan ke sejumlah stakeholder. Akan tetapi, pelaksanaan dari pemerataan pendapatan belum maksimal, yang artinya equitable distribution ratio adalah rendah. Hal ini dibuktikan dengan adanya penurunan pemberian pembiayaan qard (pemangku kepentingan adalah masyarakat) padahal laba meningkat (pemangku kepentingan perusahaan). Statistik Perbankan Syariah tahun 2014 menunjukkan bahwa pembiayaan qard pada tahun 2010, 2011, 2012, 2013 secara berturut-turut yaitu 4,73 triliun, 12,93 triliun, 12,09 triliun, 8,9 triliun. Sedangkan jumlah laba bersih 2010-2013 yaitu 527 milyar, 1,06 triliun, 1,89 triliun, 3, 18 triliun. Pada pembiayaan qard terdapat penurunan, sedangkan pada laba bersih terdapat peningkatan.

Director-employees welfare ratio mengindikasi jumlah uang yang digunakan untuk direktur dan jumlah uang untuk kesejahteraan pegawai. Hal ini dikarenakan adanya isu-isu renumerasi direktur. Banyak yang mengungkapkan bahwa direktur digaji lebih dibanding pekerjaan yang dia lakukan.

Islamic investment vs non-Islamic investment mengukur dan mengidentifikasi sejauh mana perbankan syariah melakukan transaksi yang halal dibandingkan dengan transaksi yang mengandung riba, gharar, dan judi. Sedangkan Islamic income vs nonIslamic income bertujuan untuk mengukur pendapatan yang bersumber dari pendapatan yang halal. Prinsip Islam melarang adanya transaksi riba, gharar, dan maysir dan mewajibkan perdagangan yang halal. Akan tetapi, masih terdapat perbankan syariah 


\section{JURNAL NOMINAL / VOLUME V NOMOR 1 / TAHUN 2016}

yang melakukan transaksi tidak halal yang mengandung riba, seperti transaksi pada bank konvensional dan mendapatkan laba atau biasanya disebut pendapatan konvensional.

Dari ketujuh rasio pada Islamicity performance index, tidak semua digunakan dalam pengukuran kinerja keuangan. Hal ini dikarenakan adanya beberapa kekurangan. Ukuran Islamic investment vs non-Islamic investment tidak digunakan pada penelitian yang sekarang dikarenakan rasio ini menggambarkan keadaan Dewan Pengawas Syariah (DPS) pada perbankan syariah. Keberadaan DPS memberikan jaminan bahwa perbankan syariah tidak melakukan investasi yang tidak halal, sehingga hal ini tidak dapat ditelusur pada laporan keuangan. Director-employees welfare ratio dan AAOIFI index tidak digunakan karena rasio tersebut tidak berpengaruh pada pengukuran kinerja secara agregat dan rasio tersebut merupakan pertimbangan bersifat kualitatif a. (Fovana, 2008 dalam Nanda Harianto, 2013).

Berdasarkan latar belakang di atas, peneliti tertarik untuk melakukan penelitian dengan judul "Pengaruh Intellectual Capital dan Islamicity Performance Index terhadap Kinerja Keuangan Perbankan Syariah di Indonesia”. Penelitian menggunakan sampel Bank Umum Syariah yang terdaftar pada Bank Indonesia periode 2010-2015.

\section{METODE PENELITIAN}

\section{Jenis Penelitian}

Jenis penelitian ini merupakan penelitian kausal komparatif. Penelitian ini bersifat sebab akibat, di mana terdapat hubungan antara variabel yang digunakan dalam penelitian.

\section{Waktu dan Tempat Penelitian}

Data yang digunakan merupakan laporan keuangan perbankan syariah periode 20102015. Data dapat diakses melalui website http://www.ojk.go.id dan website masingmasing perbankan.

\section{Populasi dan Sampel}

Populasi dalam penelitian ini merupakan Bank Umum Syariah (BUS) yang terdaftar di Bank Indonesia periode 2010-2015, yaitu sebanyak 12 unit Bank Umum Syariah. Sampel dipilih berdasarkan purposive sampling method.

Sampel yang diambil pada penelitian ini dipilih berdasarkan kriteria sebagai berikut: Bank Umum Syariah yang terdaftar di Bank Indonesia pada periode 2015.

b. Tidak mengalami perubahan bentuk badan usaha pada periode 2010-2015. Hal ini dilakukan dengan tujuan agar tidak terdapat perubahan konsistensi akuntansi dalam laporan keuangan dan agar variabel yang digunakan dalam penelitian dapat dibandingkan.

c. Bank Umum Syariah menyediakan laporan keuangan tahunan secara lengkap pada periode 2010-2015 yang 


\section{JURNAL NOMINAL / VOLUME V NOMOR 1 / TAHUN 2016}

dibutuhkan dalam penelitian. Kriteria kelengkapan yaitu menyajikan laporan keuangan berupa: laporan posisi keuangan, laporan laba rugi, laporan perubahan ekuitas, laporan arus kas, laporan sumber dan penyaluran dana zakat, laporan sumber dan penggunaan dana kebajikan, dan catatan atas laporan keuangan.Berdasarkan kriteria, diperoleh 5 Bank Umum Syariah sebagai sampel. Total jumlah data yang digunakan dalam penelitian yaitu 30 laporan keuangan perbankan syariah.

Berdasarkan kriteria, diperoleh 5 Bank Umum Syariah sebagai sampel. Total jumlah data yang digunakan dalam penelitian yaitu 30 laporan keuangan perbankan syariah.

\section{Prosedur}

Data yang digunakan yaitu data sekunder. Data diperoleh dari laporan keuangan tahunan perbankan syariah di Indonesia pada periode 2010-2015. Metode pengumpulan data yaitu metode dokumentasi.

Data yang diperoleh kemudian dihitung nilai kinerja keuangan (ROA), Intellectual Capital, dan rasio Islamicity performance Index (profit sharing ratio, zakat performing ratio, equitable distribution ratio, dan Islamic income vs non-Islamic income).

Kinerja Keuangan (Y) yang diproksikan dengan ROA dihitung dengan membandingkan laba bersih dengan total aset. Untuk mengetahui besar pengembalian aset digunakan laba bersih agar diketahui total bersih keuntungan dari penggunaan aset perusahaan.

$$
\mathrm{ROA}=\frac{\text { Laba Bersih }}{\text { Total Aset }}
$$

(Ross et. al., 2009:90)

Intellectual capital $\left(\mathrm{X}_{1}\right)$ diukur berdasarkan value added yang diciptakan oleh costumer capital (VACA), human capital (VAHU), dan structural capital (STVA). Kombinasi dari ketiga value added tersebut merupakan instrument yang dikembangkan oleh Pulic pada tahun 1997. Instrument tersebut bernama VAIC ${ }^{\mathrm{TM}}$, yaitu value added intellectual coefficient.

Dalam mengukur kinerja intellectual capital menggunakan VAIC ${ }^{\mathrm{TM}}$ terdapat lima tahapan yang harus dilakukan. Tahapan yang pertama yaitu menghitung Value Added (VA).

$$
\mathrm{VA}=\mathrm{OUT}-\mathrm{IN}
$$

Keterangan:

$\mathrm{VA}=$ Value Added

OUT = Output (total pendapatan)

IN = Input (total beban selain beban karyawan)

(Ihyaul Ulum, 2009:88)

Tahap kedua adalah menghitung nilai Value Added Capital Employed (VACA). VACA merupakan suatu indikator untuk 


\section{JURNAL NOMINAL / VOLUME V NOMOR 1 / TAHUN 2016}

value added yang diciptakan oleh satu unit dari physical capital (Ihyaul Ulum, 2009:87). VACA membandingkan Value Added (VA) dengan jumlah Capital Employed (CE). CE dapat dilihat pada jumlah dana yang tersedia pada perusahaan atau ekuitas yang dimiliki perusahaan. Rasio ini menunjukkan kontribusi dari CE terhadap VA perusahaan. Semakin besar nilai VACA maka semakin baik bagi perusahaan, karena hal tersebut menunjukkan semakin besar kontribusi dari CE untuk meningkatkan nilai perusahaan.

Tahap ketiga yaitu menghitung nilai human capital (VAHU). VAHU adalah rasio dari VA terhadap Human Capital (HU). Rasio ini mengukur kontribusi yang dibuat dari setiap rupiah yang diinvestasikan dari HC terhadap VA perusahaan.

Tahap selanjutnya adalah menghitung nilai tambah structural capital (STVA). STVA (Structural Capital Value Added) adalah rasiodari Structural Capital (SC) terhadap VA. SC diperoleh dari pengurangan VA dengan HC.

Tahap terakhir dalam mengukur intellectual capital adalah menghitung $\mathrm{VAIC}^{\mathrm{TM}}$. VAIC ${ }^{\mathrm{TM}}$ merupakan penjumlahan dari komponen-komponennya, yaitu VACA, VAHU, dan STVA.

Profit Sharing Ratio $\left(\mathrm{X}_{2}\right)$ adalah rasio pembiayaan mudharabah dan musyarakah terhadap total pembiayaan. Rasio ini mengukur banyaknya bagi hasil yang dicapai oleh perbankan syariah, yang diperoleh dengan pembiayaan mudharabah dan pembiayaan musyarakah.

Zakat Performing Ratio $\left(\mathrm{X}_{3}\right)$ merupakan rasio zakat terhadap total aset bersih. Dalam hal ini zakat yang dibayarkan oleh perbankan syariah menjadi dasar dalam pengukuran kinerja perbankan syariah. Zakat yang dibayarkan perbankan syariah menggantikan indikator laba per saham.

Equitable Distribution Ratio

$\left(\mathrm{X}_{4}\right)$ mengukur distribusi kepada setiap pemangku kepentingan. Pihak pemangku kepentingan dibedakan menjadi empat kelompok, yaitu pemegang saham, masyarakat, karyawan, dan perusahaan. Rasio ini dipresentasikan oleh jumlah qard dan dana kebajikan, upah karyawan, dividen, dan laba bersih. Rata-rata distribusi kepada setiap pemangku kepentingan kemudian dibandingkan dengan total pendapatan setelah dikurangi zakat dan pajak.

Islamic Income vs Non-Islamic Income $\left(\mathrm{X}_{5}\right)$ mengukur seberapa besar jumlah pendapatan halal yang diperoleh perbankan syariah. Islamic Income vs Non-Islamic Income merupakan rasio pendapatan halal terhadap total pendapatan. Total pendapatan terdiri data pendapatan halal dan pendapatan tidak halal. Pendapatan tidak halal diperoleh dari pendapatan dari kegiatan konvensional. Pendapatan tidak halal juga dapat dilihat pada laporan sumber dan penggunaan dana kebajikan yang disediakan oleh perbankan syariah. 


\section{JURNAL NOMINAL / VOLUME V NOMOR 1 / TAHUN 2016}

Hasil perhitungan variabel kemudian digunakan dasar analisis menggunakan IBM SPSS Statistics 20.

\section{Teknik Analisis Data}

\section{Data}

Data pada penelitian ini adalah data sekunder. Data sekunder yang digunakan berupa laporan keuangan tahunan perbankan syariah di Indonesia periode 2010-2015. Data diperoleh dengan metode dokumentasi.

\section{Teknik Analisis Data}

Teknik analisis data menggunakan analisis statistik deskriptrif, uji asumsi klasik, dan uji hipotesis. Uji asumsi klasik terdiri dari uji normalitas, multikolinieritas, autokorelasi, dan heteroskedastisitas. Uji hipotesis menggunakan analisis regresi linier sederhana dan berganda.

Uji normalitas digunakan untuk mengukur apakah data yang diambil dari populasi berdistribusi secara normal atau tidak. Pada penelitian ini, uji normalitas menggunakan Kolmogorof Smirnov Test. Data berdistribusi normal apabila nilai asymptotic significance > 0,05 (Sofyan Yamin dkk, 2011:11). Jika variabel penelitian memiliki tingkat signifikansi lebih besar dari 0,05 atau 5\%, maka dapat disimpulkan bahwa variabel penelitian tersebut berdistribusi normal.

Uji multikolonieritas digunakan untuk menguji korelasi antarvariabel independen dalam model regresi. Uji ini dilakukan pada model regresi yang memiliki dua atau lebih variabel independen. Model regresi yang baik seharusnya tidak memiliki korelasi antara variabel independen. Apabila dalam model regresi terdapat multikolonearitas, maka model tersebut memiliki kesalahan standar yang besar, sehingga menyebabkan koefisien tidak dapat ditaksir dengan ketepatan yang tinggi. Nilai cutoff yang digunakan untuk mendeteksi adanya multikolonieritas adalah nilai tolerance $\leq$ 0,10 atau sama dengan nilai VIF $\geq 10$ (Imam Ghozali, 2011:106). Terjadi atau tidaknya multikolonieritas dapat dilihat dari nilai Tolerance dan nilai Variance Inflation Factor (VIF). Jika nilai VIF kurang dari 10 dan nilai Tolerance lebih dari 0,1, maka dapat disimpulkan bahwa data yang digunakan terbebas dari multikolonieritas.

Uji autokorelasi digunakan untuk menguji apakah terdapat korelasi antar data dalam variabel penelitian pada periode $\mathrm{t}$ dengan periode sebelumnya (t-1) pada model regresi. Apabila terdapat korelasi, maka terdapat problem autokorelasi. Persamaan regresi yang baik adalah persamaan yang tidak memiliki masalah autokorelasi, jika terjadi autokorelasi maka persamaan tersebut menjadi tidak layak dipakai untuk prediksi (Danang Sunyoto, 2013:97). Uji autokorelasi dalam penelitian ini menggunakan uji Durbin-Watson (DW Test).

Uji heteroskedasitisitas bertujuan untuk menguji ada atau tidaknya suatu penyimpangan. Dengan kata lain, uji ini bertujuan untuk mengetahui adanya 


\section{JURNAL NOMINAL / VOLUME V NOMOR 1 / TAHUN 2016}

ketidaksamaan varians dari residual suatu pengamatan ke pengamatan lain dalam sebuah model regresi. Uji ini dilakukan untuk mengetahui apakah model regresi bersifat homoskedastisitas atau heteroskedastisitas. Homoskedastisitas merupakan keadaan di mana varians dari residual suatu pengamatan ke pengamatan lain adalah tetap. Apabila varians dari residual berbeda, maka model bersifat heteroskedastisitas.

Salah satu cara untuk mengetahui ada atau tidaknya heteroskedastisitas yaitu menggunakan uji Glejser. Uji Glejser dilakukan untuk meregresi nilai absolut residual terhdap variabel independen (Gujarati,2003 dalam Imam Ghozali, 2011:142). Kriteria pengambilan keputusan adalah jika signifikansi dari variabel independen lebih besar dari 0,05 atau 5\%, maka tidak terjadi masalah heteroskedastisitas (Imam Ghozali, 2011:143).

Analisis regresi sederhana digunakan berdasar hubungan kausal satu variabel independen dengan satu variabel dependen. Analisis ini dilakukan untuk membuktikan hipotesis yang diajukan, apakah intellectual capital, profit sharing ratio, zakat performing ratio, equitable distribution ratio, dan Islamic income vs non-Islamic income sebagai variabel independen berpengaruh terhadap variabel terikat yaitu kinerja keuangan. Langkah-langkah dalam melakukan analisis regresi sederhana yaitu membuat garis linier sederhana kemudian menguji signifikan uji t. Uji t menguji pengaruh variabel bebas secara individual terhadap variabel terikat. Apabila nilai $t$ hitung lebih tinggi dari nilai t tabel, hipotesis alternatif yang menyatakan variabel independen secara individual mempengaruhi variabel dependen diterima (Imam Ghozali, 2011:99). Dengan begitu, apabila t hitung lebih besar atau sama dengan t tabel, maka terdapat pengaruh variabel independen terhadap variabel dependen secara signifikan.

Analisis regresi linier berganda digunakan untuk menguji pengaruh dua atau lebih variabel independen terhadap variabel dependen dengan skala pengukuran interval dalam suatu persamaan linier. Langkah yang dilakukan yaitu membuat persamaan regresi linier berganda, mencari koefisien determinasi, kemudian melakukan uji $\mathrm{F}$. Dalam uji F, kriteria pengambilan keputusan yang dapat digunakan yaitu apabila F hitung lebih besar dari F tabel, maka hipotesis yang menyatakan bahwa variabel independen secara simultan mempengaruhi variabel dependen diterima (Imam Ghozali, 2011:98).

\section{HASIL PENELITIAN DAN PEM-} BAHASAN

\section{Analisis Statistik Deskriptif}

Analisis statistik deskriptif digunakan untuk menjelaskan variabel-variabel dalam penelitian, yang meliputi variabel dependen dan variabel independen. Variabel dependen 
Sumber: Data yang Diolah 2016

Pada penelitian ini, pengujian autokorelasi menggunakan Uji DurbinWatson. Kriteria tidak terjadi autokorelasi adalah du $<\mathrm{d}<4-\mathrm{du}$ (Imam Ghozali, 2011:111). Nilai DW sebesar 2,099 lebih besar dari du $(1,833)$ dan lebih kecil dari 4 - du yaitu 4-1,833 = 2,167 atau secara sederhana dapat dituliskan sebagai 1,833 $<2,099<2,167$. Dari uraian tersebut, dapat disimpulkan bahwa model regresi yang digunakan pada penelitian ini tidak mengalami autokorelasi antar variabel independennya.

\section{d. Uji Heteroskedastisitas}

Hasil Uji Heteroskedastisitas dapat dilihat pada tabel dibawah ini:

Tabel 4. Hasil Uji Heteroskedastisitas

\begin{tabular}{cr}
\hline Variabel & \multicolumn{1}{l}{ Sig. } \\
\hline $\mathbf{X 1}$ & 0,159 \\
\hline $\mathbf{X 2}$ & 0,078 \\
$\mathbf{X 3}$ & 0,625 \\
\hline $\mathbf{X 4}$ & 0,637 \\
\hline $\mathbf{X 5}$ & 0,658
\end{tabular}

Sumber: Data yang Diolah 2016

Tabel 4 menunjukkan bahwa semua variabel independen dalam penelitian ini mempunyai nilai signifikansi lebih besar dari 0,05 . Hal ini menunjukkan tidak terjadi masalah heteroskedastisitas

\section{Uji Hipotesis}
a. Pengaruh Intellectual Capital terhadap Kinerja Keuangan

\section{Perbankan Syariah di Indonesia}

$\mathrm{H} 1$ : terdapat pengaruh positif signifikan intellectual capital terhadap kinerja keuangan pada perbankan syariah yang terdaftar di Bank Indonesia periode 2010-2015. Hasil pengujian hipotesis 1 adalah sebagai berikut:

Tabel 5. Hasil Uji Hipotesis 1

\begin{tabular}{|c|c|c|c|}
\hline Variabel & Koef. & $\begin{array}{c}\mathrm{t} \\
\text { hitung }\end{array}$ & Sig \\
\hline Konstan & $-0,007$ & & \\
\hline $\mathbf{X}_{1}$ & 0,007 & 7,593 & 0,00 \\
\hline $\mathbf{R}$ & : $\mathbf{0 , 8 2 0}$ & & \\
\hline
\end{tabular}

Sumber : Data yang Diolah 2016

Koefisien korelasi intellectual capital yaitu sebesar 0,820 yang menunjukkan bahwa hubungan antara intellectual capital dan kinerja keuangan kuat. Selain itu, nilai koefisien determinan sebesar 0,673 menunjukkan bahwa kinerja keuangan yang dijelaskan oleh intellectual capital adalah sebesar 67,3\%. Nilai koefisien regresi intellectual capital $\left(\mathrm{X}_{1}\right)$ sebesar 0,007 yang artinya setiap kenaikan intellectual capital sebesar 1 satuan akan meningkatkan kinerja keuangan sebesar 0,007 satuan. Selain itu, t hitung lebih besar dari t tabel $(7,593>$ 2,045). Hal ini mengindikasikan bahwa 


\section{JURNAL NOMINAL / VOLUME V NOMOR 1 / TAHUN 2016}

terdapat pengaruh positif signifikan intellectual capital terhadap kinerja keuangan. Semakin baik nilai intellectual capital maka kinerja keuangan pada perbankan syariah akan semakin baik.

Intellectual capital yang dikelola dengan baik oleh perusahaan dapat menciptakan nilai tambah (value added) bagi perusahaan itu sendiri. Atas dasar nilai tambah tersebut para penyandang dana akan memberikan nilai tambah juga kepada perusahaan dengan cara berinvestasi lebih tinggi. Nilai tambah ini akan meningkatkan kinerja keuangan perusahaan.

b. Pengaruh Profit Sharing Ratio terhadap Kinerja Keuangan Perbankan Syariah di Indonesia

$\mathrm{H} 2$ : terdapat pengaruh signifikan profit sharing ratio terhadap kinerja keuangan pada perbankan syariah yang terdaftar di Bank Indonesia periode 2010-2015.

Tabel 6. Hasil Uji Hipotesis 2

\begin{tabular}{lccc}
\hline Variabel & Koef. & \multicolumn{1}{c}{ S } & Sig \\
& & \\
hitung & \\
\hline Konstan & 0,010 & & \\
\hline $\mathbf{X}_{1}$ & $-0,011$ & $-2,056$ & 0,049 \\
\hline $\mathbf{R}$ & $\mathbf{0 0 , 3 6 2}$ & & \\
\hline R Square & $\mathbf{0} \mathbf{0 , 1 3 1}$ & & \\
\hline
\end{tabular}

Sumber : Data yang Diolah 2016

Koefisien korelasi profit sharing ratio sebesar 0,362 menunjukkan hubungan antara profit sharing ratio dan kinerja keuangan adalah lemah. Selain itu, nilai koefisien determinan sebesar 0,131 menunjukkan bahwa kinerja keuangan yang dijelaskan oleh profit sharing ratio sebesar $13,1 \%$. Nilai koefisien regresi profit sharing ratio $\left(\mathrm{X}_{2}\right)$ sebesar 0,010 yang artinya setiap kenaikan profit sharing ratio sebesar 1 satuan akan menurunkan kinerja keuangan sebesar 0,011 satuan. Selain itu, t hitung lebih besar dari t tabel $(2,056>2,045)$. Hal ini mengindikasikan bahwa semakin meningkat nilai profit sharing ratio maka kinerja keuangan pada perbankan syariah akan menurun.

Pada penelitian ini profit sharing ratio meningkat dan menyebabkan penurunan kinerja keuangan. Hal ini dapat terjadi dikarenakan adanya faktor lain yang mempengaruhi selain profit sharing ratio. Adanya kerugian pada bisnis yang dijalankan dapat menyebabkan turunnya kinerja keuangan. Selain itu, adanya indikasi pembiayaan yang tidak lancar juga dapat mempengaruhi rendahnya kinerja keuangan Apabila dilihat pada angka Non Performing Financing (NPF), angka yang ditunjukan pada tahun 20102015 mengalami fluktuasi. Meningkatnya nilai NPF mengakibatkan adanya penurunan pada kinerja keuangan. Walaupun jumlah pembiayaan bagi hasil semakin banyak, akan tetapi apabila tidak banyak nasabah yang melunasi atau 


\section{JURNAL NOMINAL / VOLUME V NOMOR 1 / TAHUN 2016}

membayar justru akan menurunkan kinerja keuangan perbankan syariah.

Penelitian ini mendukung penelitian yang dilakukan oleh Siti Maisaroh (2015). Hasil penelitian Siti Maisaroh (2015) menunjukkan bahwa profit sharing ratio berpengaruh terhadap profitabilitas yang diproksikan dengan ROA. Karena jumlah pembiayaan bagi hasil relatif kecil dibanding pembiayaan jual beli, maka sumbangan bagi hasil kurang mampu mengoptimalkan kemampuan Bank Umum Syariah dalam menghasilkan laba. Pada akhirnya hal ini berdampak pada adanya sedikit penurunan laba ataupun ROA Bank Umum Syariah.

\section{c. Pengaruh Zakat Performing Ratio} terhadap Kinerja Keuangan

\section{Perbankan Syariah di Indonesia}

H3 : terdapat pengaruh signifikan zakat performing ratio terhadap kinerja keuangan pada perbankan syariah yang terdaftar di Bank Indonesia periode 20102015. Hasil pengujian hipotesis 3 adalah sebagai berikut:

Tabel 7. Hasil Uji Hipotesis 3

\begin{tabular}{lccc}
\hline Variabel & Koef. & $\begin{array}{c}\text { t } \\
\text { hitung }\end{array}$ & Sig \\
& & & \\
\hline Konstan & 0,006 & & \\
\hline $\mathbf{X}_{1}$ & 4,823 & 1,494 & 0,146 \\
\hline $\mathbf{R}$ & $\mathbf{0} \mathbf{0 , 2 7 2}$ & & \\
\hline $\boldsymbol{R}$ Square & $\mathbf{0} \mathbf{0 , 0 7 4}$ & & \\
\hline
\end{tabular}

Sumber: Data yang Diolah 2016
Nilai koefisien regresi zakat performing ratio $\left(\mathrm{X}_{3}\right)$ sebesar 4,823 yang artinya setiap kenaikan zakat performing ratio sebesar 1 satuan akan menaikkan kinerja keuangan sebesar 4,823 satuan. Nilai t hitung lebih kecil dari t tabel $(1,494<$ 2,045). Hal ini mengindikasikan bahwa tidak terdapat pengaruh signifikan zakat performing ratio terhadap kinerja keuangan. Perubahan nilai pada zakat performing ratio tidak mempengaruhi kinerja keuangan pada perbankan syariah. Hal ini mengindikasikan bahwa terdapat faktor lain yang mempengaruhi kinerja keuangan selain zakat.

Sumber dana zakat perbankan syariah terdiri atas zakat dari dalam entitas perbankan syariah dan dana zakat dari pihak luar entitas perbankan syariah. Zakat dari dalam entitas perbankan syariah merupakan pengeluaran zakat oleh perbankan syariah atas aset yang dimiliki, sedangkan zakat dari luar entitas merupakan zakat yang berasal dari nasabah dan umum. Jumlah zakat yang dikeluarkan oleh perbankan syariah masih relatif kecil, sehingga dana yang digunakan sebagian besar didominasi oleh zakat dari luar entitas perbankan. Hal ini mengakibatkan jumlah pembayaran zakat tidak mempengaruhi kinerja perbankan syariah. 
d. Pengaruh Equitable Distribution Ratio terhadap Kinerja Keuangan Perbankan Syariah di Indonesia 4

H4 : terdapat pengaruh signifikan equitable distribution ratio terhadap kinerja keuangan pada perbankan syariah yang terdaftar di Bank Indonesia periode 2010-2015.

Tabel 8. Hasil Uji Hipotesis 4

\begin{tabular}{lccc}
\hline Variabel & Koef. & $\begin{array}{c}\text { t } \\
\text { hitung }\end{array}$ & Sig \\
& \multicolumn{3}{c}{} \\
\hline Konstan & 0,006 & & \\
\hline $\mathbf{X}_{1}$ & 0,010 & 1,279 & 0,211 \\
\hline $\mathbf{R}$ & $\mathbf{0} \mathbf{0 , 2 3 5}$ & & \\
\hline R Square & $\mathbf{0} \mathbf{0 , 0 5 5}$ & & \\
\hline
\end{tabular}

Sumber: Data yang Diolah 2016

Nilai t hitung lebih kecil dari t tabel (1,279

$<2,045)$. Hal ini mengindikasikan bahwa tidak terdapat pengaruh signifikan equitable distribution ratio terhadap kinerja keuangan. Perubahan nilai pada equitable distribution ratio tidak mempengaruhi kinerja keuangan pada perbankan syariah.

Penelitian ini mendukung penelitian yang dilakukan oleh Kurniawan (2010) dan Siti Maisaroh (2015). Dalam penelitiannya, Kurniawan (2010) menjelaskan bahwa pembiayaan akad qard (termasuk dalam rasio EDR) kurang sedikit komersil jika dibandingkan dengan akad pembiayaan lain.
Pemerataan pendapatan yang dilakukan oleh perbankan syariah tidak mempengaruhi kinerja keuangan. Hal ini disebabkan adanya faktor lain yang mempengaruhi kinerja keuangan. Selain itu, pemerataan pendapatan masih terbatas pada beberapa pemangku kepentingan. Berdasarkan rasio pemerataan pendapatan (EDR), rata-rata perbankan syariah lebih menekankan alokasi pendapatan antara pemangku utama, yaitu karyawan dan perbankan syariah itu sendiri. Distribusi pendapatan kepada pemegang saham dan masyarakat relatif rendah.

e. Pengaruh Islamic Income vs Non-Islamic Income terhadap Kinerja Keuangan Perbankan Syariah di Indonesia

H5 : terdapat pengaruh signifikan Islamic income vs non-Islamic income terhadap kinerja keuangan pada perbankan syariah yang terdaftar di Bank Indonesia periode 2010-2015.

Tabel 9. Hasil Uji Hipotesis 5

\begin{tabular}{lccc}
\hline Variabel & Koef. & $\begin{array}{c}\text { t } \\
\text { hitung }\end{array}$ & Sig \\
& & & \\
\hline Konstan & $-0,013$ & & \\
\hline $\mathbf{X}_{\mathbf{1}}$ & 0,023 & 0,654 & 0,519 \\
\hline $\mathbf{R}$ & $\mathbf{0} \mathbf{0 , 1 2 3}$ & & \\
\hline R Square & $\mathbf{: 0 , 0 1 5}$ & & \\
\hline
\end{tabular}

Sumber: Data yang Diolah 2016

Nilai t hitung lebih kecil dari t tabel $(0,654$ $<$ 2,045). Hal ini mengindikasikan bahwa tidak terdapat pengaruh signifikan Islamic 


\section{JURNAL NOMINAL / VOLUME V NOMOR 1 / TAHUN 2016}

income vs non-Islamic ratio terhadap kinerja keuangan.

Perubahan nilai pada Islamic income vs non-Islamic ratio tidak mempengaruhi kinerja keuangan pada perbankan syariah. Hal ini karena adanya faktor lain sebesar 98,5\% yang mempengaruhi kinerja keuangan. Selain itu, sumber utama aktivitas tanggung jawab sosial perbankan syariah (pendapatan halal dan non halal) berasal dari dana kebajikan dan dana sosial lain yang juga dihimpun oleh perbankan syariah. Jadi, pendapatan operasional bank tidak akan mempengaruhi kinerja keuangan perbankan syariah.

Pada praktiknya, saat ini dana non halal atau pendapatan non halal menjadi bagian dari dana yang tidak bisa dihindarkan. Pada catatan atas laporan keuangan disebutkan bahwa dana kebajikan pada perbankan syariah merupakan penerimaan denda nasabah pembiayaan dan jasa giro dari bank non syariah atau konvensional. Perbankan syariah yang memperoleh pendapatan non halal dari kegiatan konvensional membuktikan bahwa perbankan tersebut belum melakukan kegiatan sesuai dengan prinsip Islam. Selain itu, adanya dana non halal ini kemudian disalurkan sebagai dana kebajikan (diberikan sebagai sumbangan dan disalurkan ke lembaga lain). Hal ini menimbulkan adanya pro dan kontra. Pendapatan non halal yang diperoleh perbankan syariah pada dasarnya haram hukumnya, akan tetapi justru diberikan sebagai sumbangan (dana kebajikan). Walaupun digunakan untuk kebajikan, akan tetapi tetap saja dana tersebut merupakan dana yang bersumber dari pendapatan tidak halal.

\section{Pengujian Hipotesis 6}

H6 : terdapat pengaruh positif signifikan intellectual capital, profit sharing ratio, zakat performing ratio, equitable distribution ratio, dan Islamicity income vs non-Islamic income secara simultan terhadap kinerja keuangan pada perbankan syariah yang terdaftar di Bank Indonesia periode 20102015.

Nilai koefisien korelasi sebesar 0,840 menunjukkan bahwa hubungan antara intellectual capital, profit sharing ratio, zakat performing ratio, equitable distribution ratio, dan Islamicity income vs non-Islamic income secara bersama-sama dengan kinerja keuangan adalah kuat. Selain itu, nilai koefisien determinasi sebesar 0,705 menunjukkan bahwa kinerja keuangan yang dijelaskan oleh intellectual capital, profit sharing ratio, zakat performing ratio, equitable distribution ratio, dan Islamicity income vs non-Islamic income sebesar $70,5 \%$, sedangkan sisanya $29,5 \%$ dijelaskan oleh sebab-sebab lain di luar penelitian ini. 


\section{JURNAL NOMINAL / VOLUME V NOMOR 1 / TAHUN 2016}

Tabel 10. Hasil Uji Hipotesis 6

\begin{tabular}{lc}
\hline Keterangan & $\begin{array}{c}\text { Koefisien } \\
\text { Regresi }\end{array}$ \\
\hline Konstanta & 0,001 \\
\hline X1 & 0,007 \\
\hline X2 & $-0,007$ \\
\hline X3 & $-3,215$ \\
\hline X4 & $-0,001$ \\
\hline X5 & $-0,005$ \\
\hline R & $=0,840$ \\
R Square & $=0,705$ \\
F hitung & $=11,489$ \\
F tabel & $=2,62$ \\
Sig F & $=0,000$
\end{tabular}

Sumber: Data yang Diolah 2016

Secara simultan, semakin tinggi Intellectual Capital, Profit Sharing Ratio, Zakat Performing Ratio, Equitable Distribution Ratio, dan Islamic Income vs Non-Islamic Income, maka akan semakin tinggi pula Kinerja Keuangan Perbankan Syariah di Indonesia. Hal ini ditunjukkan dengan nilai $\mathrm{F}$ hitung yang lebih besar dari $\mathrm{F}$ tabel $(11,489>2,62)$ dan signifikansi lebih kecil dari 0,050 yaitu sebesar 0,000.

\section{SIMPULAN DAN SARAN}

\section{Simpulan}

Berdasarkan hasil analisis data, maka dapat ditarik kesimpulan sebagai berikut:

a. Terdapat pengaruh positif signifikan Intellectual Capital terhadap kinerja keuangan perbankan syariah di Indonesia. b. Terdapat pengaruh signifikan Profit Sharing Ratio terhadap kinerja keuangan perbankan syariah di Indonesia.

c. Tidak terdapat pengaruh signifikan Zakat Performing Ratio terhadap kinerja keuangan perbankan syariah di Indonesia.

d. Tidak terdapat pengaruh signifikan Equitable Distribution Ratio terhadap kinerja keuangan perbankan syariah di Indonesia.

e. Tidak terdapat pengaruh signifikan Islamic Income vs Non-Islamic Income terhadap kinerja keuangan perbankan syariah di Indonesia.

f. Terdapat pengaruh positif signifikan Intellectual Capital, Profit Sharing Ratio, Zakat Performing Ratio, Equitable Distribution Ratio, dan Islamic Income vs Non-Islamic Income terhadap kinerja keuangan perbankan syariah di Indonesia.

\section{Saran}

Berdasarkan hasil penelitian dan terkait dengan keterbatasan penelitian ini, selanjutnya dapat diusulkan saran yang diharapkan dapat bermanfaaat yaitu sebagai berikut:

a. Bagi Manajemen Perbankan Syariah

1) Manajemen Perbankan Syariah sebaiknya selalu memberikan perhatian terhadap modal intelektual yang dimiliki.

2) Manajemen Perbankan Syariah sebaiknya tidak hanya berorientasi terhadap tingginya pembiayaan bagi hasil, akan tetapi prosedur pemberian pembiayaan juga harus diperhatikan. 


\section{JURNAL NOMINAL / VOLUME V NOMOR 1 / TAHUN 2016}

3) Manajemen Perbankan Syariah sebaiknya tidak hanya menekankan alokasi pemerataan hanya pada karyawan dan perbankan sendiri, melainkan juga pada masyarakat dan pemegang saham.

b. Bagi Peneliti Selanjutnya

1) Bagi peneliti selanjutnya yang tertarik untuk melakukan kajian di bidang yang sama dapat menambah variabel independen maupun variabel dependen.

2) Bagi peneliti selanjutnya alangkah lebih baik jika menambah proksi kinerja keuangan, tidak hanya menggunakan ukuran ROA saja.

3) Pada penelitian selanjutnya sebaiknya jumlah populasi serta sampel ditambah dan diperluas agar penelitian dapat digeneralisasikan secara baik.

\section{DAFTAR PUSTAKA}

Bank BCA Syariah. 2016. Laporan Tahunan 2010-2015. Online. (Website http://www.bcasyariah.co.id diakses 1 Juni 2016).

Bank BNI Syariah. 2016. Laporan Tahunan 2010-2015. Online. (Website http://www.bnisyariah.co.id diakses 1 Juni 2016).

Bank BRISyariah. 2016. Laporan Tahunan 2010-2015. Online. (Website http://www.brisyariah.co.id diakses 1 Juni 2016).
Bank Syariah Mandiri. 2016. Laporan Tahunan 2010-2015. Online. (Website http://www.syariahmandiri.co.id. diakses 1 Juni 2016).

Bank Syariah Mega Indonesia Syariah. 2016. Laporan Tahunan 2010-2015. Online. (Website http://www.megasyariah.co.id diakses 1 Juni 2016).

Danang Sunyoto. (2013). Analisis Regresi dan Korelasi Bivariat : Ringkasan dan Kasus. Yogyakarta: Amara Books.

Harian Kompas Tanggal 13 Agustus. (2012). Tiga Masalah Terbesar di Bank Syariah. Online. Diakses pada tanggal 1 Mei 2016 pada website

http://bisniskeuangan.kompas.com/read/201 2/08/13/15282835/Tiga.Masalah.Terbes ar.di.Bank.Syariah.

Ihyaul Ulum. (2009). Intellectual Capital: Konsep dan Kajian Empiris. Yogyakarta: Graha Ilmu.

Ikatan Akuntan Indonesia. (2009). Pernyataan Standar Akuntansi Keuangan No. 19 revisi 2000. Jakarta: Salemba Empat.

Imam Ghozali. (2011). Aplikasi Analisis Multivariate dengan Program IBM SPSS19. Semarang: Badan Penerbit Universitas Diponegoro. 
JURNAL NOMINAL / VOLUME V NOMOR 1 / TAHUN 2016

Kompasiana 26 Juni. (2015). Problematika

Pembiayaan Bagi Hasil. Online.

(Website

http://www.kompasiana.com/banksyaria

h/problematika-pembiayaan-bagi-

hasil_54ff5142a33311764c50fb7c

diakses tanggal 1 Juni 2016).

Nanda Harianto. (2013). "Pengaruh Modal Intelektual terhadap Kinerja Bisnis Bank Umum Syariah (BUS) di Indonesia". Skripsi. Fakultas Ekonomika dan Bisnis, Universitas Diponegoro.

Republika Online Tanggal 26 April. (2016). Reformat Strategi Bank Syariah. Online. Diakses pada tanggal 1 Juni 2016 pada website

http://www.republika.co.id/berita/koran/opi ni-koran/16/04/26/o68bga5-reformatstrategi-bank-syariah.

Ross, Stephen A. et.al. (2009). Modern Financial Management. New York: McGraw Hill.

Shahul Hameed et.al. (2004). Alternative Disclosure \& Performance Measures For Islamic Banks dalam Proceeding of The Second Conference on Administrative Science: Meeting The Challenges of The Globalization Age. Dahran, Saudi Arabia, 2004.
Siti Maisaroh. (2015). “Analisis Pengaruh Intellectual Capital dan Islamicity Performance Index terhadap Profitability Perbankan Syariah Indonesia”. Skripsi. Fakultas Ekonomi, UIN Maliki Malang.

Statistik Perbankan Syariah. (2016). Statistik Perbankan Syariah 2014, 2015, dan 2016. Online. Diunduh tanggal 20 Februari 2016 pada website http://www.ojk.go.id/. 